\title{
Body segments and biological maturation to estimate the propulsive force of the arm in young swimmers
}

\section{Segmentos corporais e maturação biológica para estimar a força propulsiva da braçada em jovens nadadores}

\author{
Mariana do Nascimento Sena Oliveira ${ }^{1}$ \\ (D) https://orcid.org/0000-0002-0101-0169 \\ Daniel da Rocha Queiroz ${ }^{1}$ \\ (D) https://orcid.org/0000-0002-9901-4677 \\ Marlene Salvina Fernandes da Costa ${ }^{1}$ \\ (i) https://orcid.org/0000-0002-2188-6686 \\ Arthur Henrique Oliveira da Silva ${ }^{1}$ \\ (D) https://orcid.org/0000-0002-2147-8930 \\ José Francisco da Silva ${ }^{1}$ \\ (DD https://orcid.org/0000-0003-0934-9826 \\ Marco Aurélio de Valois Correia Junior ${ }^{1}$ \\ (D) https://orcid.org/0000-0003-0386-5256 \\ Wilson Viana de Castro Melo $^{2}$ \\ (D) https://orcid.org/0000-0002-0574-7336 \\ José Cazuza de Farias Júnior ${ }^{3}$ \\ (D) https://orcid.org/0000-0002-1082-6098 \\ Marcos André Moura dos Santos ${ }^{1}$ \\ (D) https://orcid.org/0000-0002-2734-8416
}

Abstract - This study aimed to estimate the propulsive force of the arm (PFA) in young freestyle swimmers and propose an equation to estimate propulsive force, considering anthropometric variables and maturity offset. Seventy-six competitive swimmers [boys: $n=53$; age $=13.58 \pm 1.79$; girls: $n=23$; age $=12.98 \pm 1.79]$ participated in this study. Height, lean mass, sitting height, leg length, arm span, triceps skinfold, arm muscle area (AMA), and maturity offset were assessed. The propulsive force of the arm was measured by the tethered swim test. A multiple linear regression (concurrent model) was used to develop the equation using the variables AMA, arm span, and maturity offset. The Bland-Altman method was used to compare the values found between PFA and propulsive force-estimated (PFE). There was a significant correlation between the variables PFA and AMA $\left(\mathrm{R}^{2}=0.12 ; \mathrm{p}<0.01\right)$, arm $\operatorname{span}\left(\mathrm{R}^{2}=0.21 ; \mathrm{p}<0.01\right)$, and maturity offset $\left(\mathrm{R}^{2}=0.20 ; \mathrm{p}<0.01\right)$ for boys, whilst in girls theses values were: $A M A\left(R^{2}=0.07 ; p=0.20\right)$, arm $\operatorname{span}\left(R^{2}=0.50 ; p<0.01\right)$, and maturity offset $\left(\mathrm{R}^{2}=0.44 ; \mathrm{p}<0.01\right)$. Two linear equations were established to predict the PFA in boys and girls Bland-Altman analysis showed an agreement between PFA and PFE. In conclusion, the equation is a valuable tool to monitor training and help improve swimmer performance.

Key words: Anthropometry; Muscular strength; Swimming.

Resumo - Este estudo teve como objetivo estimar a força propulsora da braçada(FPB) em jovens nadadores do estilo livre e propor uma equação para estimar a força propulsora, considerando variáveis antropométricas e a maturação. Setenta e seis nadadores competitivos [meninos: $n=53$; idade $=13,58$ $\pm 1,79$; meninas: $n=23$; idade $=12,98 \pm 1,79]$ participaram deste estudo. Foram avaliados: altura, massa magra, estatura sentada, comprimento da perna, envergadura, dobra cutânea do triceps, área muscular do braço (AMB) e maturação. A força propulsiva da braçada foi medida pelo teste de nado atado. Uma regressão linear múltipla (modelo concorrente) foi usada para desenvolver a equação usando as variáveis $A M B$, envergadura e maturação. O método de Bland-Altman foi utilizado para comparar os valores encontrados entre FPB e força propulsiva estimada (FPE). Houve correlação significativa entre as variáveis $F P B$ e $A M B\left(R^{2}=0,12 ; p<0,01\right)$, envergadura $\left(R^{2}=0,21\right.$; $p<0,01)$ e maturação $\left(R^{2}=0,20 ; p<0,01\right)$ para meninos, enquanto os valores das meninas foram: $A M B\left(R^{2}=0,07 ; p=0,20\right)$, envergadura $\left(R^{2}=0,50 ; p<0,01\right)$ e maturação $\left(R^{2}=0,44 ; p<0,01\right)$. $D$ uas equaçöes lineares foram estabelecidas para predizer a FPB em meninos e meninas. A análise de Bland-Altman mostrou concordância entre FPB e FPE. Em conclusão, a equação é uma ferramenta valiosa para monitorar o treinamento e ajudar a melhorar o desempenho do nadador.

Palavras-chave: Antropometria; Força muscular; Natação.
1 Universidade de Pernambuco. Escola Superior de Educação Física. Recife, PE, Brasil

2 Universidade Federal de Pernambuco. Núcleo de Educação Física e Ciências do Esporte. Vitória de Santo Antão, PE. Brasil

3 Universidade Federal da Paraíba. João Pessoa, PB. Brasil.

Received: June 18, 2020 Accepted: October 10, 2020

How to cite this article Oliveira MNS, Queiroz DR, Costa MSF, Silva AHO, Silva JF, Correia Junior MAV, Viana WCM, Farias Júnior JC, Santos MAM. Body segments and biological maturation to estimate the propulsive force of the arm in young swimmers. Rev Bras Cineantropom Desempenho Hum 2020, 22:e74881. DOI: http://dx.doi. org/10.1590/1980-0037.2020v22e74881.

Copyright: This work is licensed under a Creative Commons Attribution 4.0 International License. 


\section{INTRODUCTION}

Performance in different competitive swimming events and tests may be explained by biomechanical parameters, cardiorespiratory fitness, propulsive force, resistance in the aquatic environment, and technical factors ${ }^{1,2}$. In dynamic equilibrium conditions, the propulsive force generated by the swimmer is proportional to the pulling force provided by the active fluid against the trajectory of body displacement ${ }^{3}$. Thus, the inclusion of upper limb strength seems crucial to increase the propulsion levels used in water.

In this context, several studies have been conducted to find out how large the correlation is between anthropometric indicators and swimming performance of young swimmers, and which of these indicators has the greatest impact on swimming performance ${ }^{5-8}$. Over short distances, episodes of sprints are quite common and depend directly on muscular power, since the swimmer needs to reach higher speeds ${ }^{9}$.

According to the literature, the stroke rate, stroke index, arm span, body height, bone mass, spine bone mineral density, foot size, and leg strength could be used as predictors of $100-\mathrm{m}$ and $400-\mathrm{m}$ front crawl performance in young swimmers ${ }^{7,10,11}$. For example, Sammound et al. ${ }^{11}$ revealed that $100-\mathrm{m}$ butterfly speed performance was strongly and positively associated with the segment length ratio [(arm-span)/(forearm-length) and girth ratio (calfgirth)/(ankle-girth), rather than the whole-body size characteristics. Nevill et al. ${ }^{7}$ showed that lean body mass was the singularly most important wholebody characteristic associated with front crawl swim speeds and that having greater limb segment length ratios [i.e., arm ratio = (lower arm)/(upper arm); foot-to-leg ratio $=($ foot $) /($ lower-leg $)]$ were key to personal best swim speeds.

Propulsive force in swimming is paramount for performance and this assessment gives a direct estimation of the force through water that is specific to swimmers ${ }^{3,12}$. Some studies have shown a direct relationship between power and speed and imply that high levels of power are transferred positively to the travel speed through water ${ }^{13,14}$. For instance, Santos et al. ${ }^{8}$ found a positive association $(r=0.68 ; \mathrm{p}<0,001)$ between arm muscle area and propulsive force of the arm (PFA) in young male swimmers ( 9 to 14 years).Geladas et al. ${ }^{15}$ reported that 100 -m freestyle swimming performance was best predicted by a combination of anthropometric and physical tests $(r=-0.22$ to -0.31$)$ in a sample of 263 (12-14-year-old) swimmers. Efforts have been made to seek effective, reliable, and practical means of assessing and monitoring changes in this capacity.

Understanding the association between anthropometric variables and swimming performance has been shown to be an important factor, not only in the identification of future talents in swimming ${ }^{11}$ but also in the possibility of developing predictive models and equations that better seek to explain these relationships. Prediction equations, resulting from direct measurement tests, have contributed as low cost and applicable valuation methods. In swimming, for instance, it is possible to identify these equations from the anthropometric viewpoint, estimating the propulsive force 
of swimming at the critical speed as well as validating tests to determine aerobic capacity ${ }^{8,16}$.

Despite the recognized importance of the propulsive force of swimmers, few studies have developed, in adolescents, equations using anthropometric factors and maturity offset to estimate propulsive force. Therefore, the purpose of this study was to estimate the propulsive force of the arm in young freestyle swimmers and propose an equation to estimate propulsive force, considering anthropometric variables and maturity offset.

\section{METHOD}

This study was conducted in Pernambuco (Brazil) with swimmers registered at the Brazilian Federation of Aquatic Sports. Fifty-three boys (13.58 \pm 1.79 years $)$ and twenty-three girls $(12.96 \pm 1.79$ years), who trained for two hours per day, six times per week, participated in this study. The subjects participated in the following steps of the study: (a) description of the study; (b) anthropometric measurements; (c) measurement of the propulsive force of the arm. Written informed assent (children and adolescents) / consent (legal representatives) were obtained before the start of the study. This study was approved by the Ethics Committee on Human Research (CAAE-23474613.6.0000.5207).

\section{Anthropometric measurements}

Height and sitting height were measured to the nearest $1.0 \mathrm{~cm}$ using a portable stadiometer (Sanny, São Paulo, Brazil). Leg length was indirectly obtained by subtracting the value of the sitting height from the height. Body mass was measured to the nearest $0.1 \mathrm{~kg}$ with a digital scale (Filizola, São Paulo, Brazil). The arm span was obtained to the nearest $0.1 \mathrm{~cm}$ using a tape measure (Starrett, Itu, Brazil) with the individual standing with arms abducted at a $90^{\circ}$ angle with the trunk, elbows extended, and forearms supinated. The distance between the $3^{\text {rd }}$ finger of the right and left hand in this position was taken as the arm span.

The circumference of the arm (relaxed) was measured by a single evaluator with a $0.1 \mathrm{~cm}$ precision flexible tape. Skinfold measurements (in millimeters) were taken on the right-hand side of the triceps using a Lange skinfold caliper (Lange, Santa Cruz, CA). The arm muscle area was calculated by the equation: AMA $\left(\mathrm{cm}^{2}\right)=\{[\mathrm{AC}-\pi \cdot \mathrm{TST}(\mathrm{cm} 2)] / 4 \cdot \pi\}$, where AMA is relaxed AMA, AC is arm circumference, TST is triceps skinfold thickness, and $\pi=3.1416$.

\section{Biological maturation}

Biological maturation was assessed using maturity offset $\left(M_{\text {off }}\right)$, which provides an indication of somatic maturity based on measured height, sitting height, and leg length, described previously by Mirwald et al. ${ }^{17}$. In girls, maturity offset $=-9.376+(0.0001882 \cdot \mathrm{leg}$ length and sitting height interaction $)+(0.0022 \cdot$ age and leg length interaction $)+(0.005841 \cdot$ age 
and sitting height interaction) - (0.002658 age and weight interaction) + $(0.07693 \cdot$ weight by height ratio $\times 100)$. In boys, maturity offset $=-9.236+$ $(0.0002708 \cdot \mathrm{leg}$ length and sitting height interaction) $-(0.001663 \cdot$ age and leg length interaction $)+(0.007216$ age and sitting height interaction $)+$ $(0.02292 \cdot$ weight by height ratio $\times 100)$. In the main analyses, biological maturation was treated continuously.

\section{Propulsive force of the arm}

Propulsive force was measured using the fully tethered swimming method composed of a load cell with a maximum nominal load of $2000 \mathrm{~N}( \pm 0.29$ $\mathrm{N})$, tied to the athlete's hip with a system of cables and the starting block with an aluminum bracket. The cable system was attached at a distance of approximately three centimeters from the waterline ${ }^{12}$. The swimmer did not exercise during the 24 hours preceding the tests. This precaution was taken so that no acute effect resulting from the training sessions could influence the results. A 10-minute warm-up period of exercise subjectively determined by the swimmer as moderate-intensity was performed before the beginning of the evaluation. A leg float was placed between the legs of the swimmer to prevent unwanted movements with the lower limbs. The protocol to evaluate the propulsive force of the arm consisted of applying two maximal efforts in front crawl while tied to the measurement apparatus for 30 seconds. The beginning and finish of the test were determined by an audible signal and all participants were verbally encouraged to give maximum performance. In the present study, we only used the maximal efforts (kgf) analyzed in the Software EMG System, [(EMG Lab V1.2) EMG System, SP, Brazil]. The load cell was a force transducer with a traction capacity of $300 \mathrm{~kg}$. Water temperature was kept between $25^{\circ}$ and $28^{\circ}$, as recommended by the Fédération Internationale de Natation for swimming performance.

\section{Statistical analyses}

All statistical analysis was performed using the software SPSS, version 21.0. and GraphPad Prism 6. Statistical normality was tested using both statistical (Kolmogorov-Smirnov test) and graphical procedures (normal probability plots). The continuous variables are expressed as mean, standard deviation, and minimum and maximum values. The assumption of a linear relationship between each independent variable and propulsive force of the arm was checked using scatterplots, and the lack of collinearity by the Pearson coefficients ( $\mathrm{r}<0.6)$. A concurrent model was conducted, using the forward method, for the development of the prediction equation of the propulsive force of the arm by adjusted R-square and deviance statistic. The deviance is the measure of model goodness of fit, and it is expected that if a new model fits the data better than the previous one, the deviance will drop significantly. Furthermore, the change in deviances $(\Delta \mathrm{D})$ follows a chi-square distribution whose degrees of freedom are calculated from the difference between the numbers of the estimated parameters in each 
model, assuming they are nested within each other. In model 1, we used the arm muscle area as an independent variable. In model 2, we added arm span to the model, and in model 3 we added maturity offset. Residual analysis was performed by checking for normality and homoscedasticity using graphical analysis, and multicollinearity using the criterion variance inflation factors (VIF > 5). Subsequently, the Bland-Altman method was used for the concordance values found between the propulsive force of the arm (PFA) and arm propulsive force-estimated (PFE). Statistical significance was set at $\mathrm{p} \leq 0.05$.

\section{RESULTS}

Descriptive statistics (means $\pm \mathrm{SD}=$ standard deviations) of the sample are shown in Table 1. On average, boys were older, heavier, and taller, as well as having higher propulsive force of the arm, sitting height, arm span, arm muscle area, and fat-free mass than girls. On the other hand, maturity offset in girls was earlier than in boys.

Table 1. Descriptive analyses of swimming athletes

\begin{tabular}{lcccccc}
\hline & & $\begin{array}{c}\text { Boys } \\
(\mathrm{n}=53)\end{array}$ & & & \multicolumn{2}{c}{$\begin{array}{c}\text { Girls } \\
(\mathrm{n}=23)\end{array}$} \\
\hline & Mean $\pm \mathrm{SD}$ & Minimum & Maximum & Mean $\pm \mathrm{SD}$ & Minimum & Maximum \\
\hline Age (years) & $13.58 \pm 1.79$ & 9.00 & 17.00 & $12.96 \pm 1.71$ & 9.00 & 16.00 \\
Body Height (cm) & $165.31 \pm 11.15$ & 133.00 & 187.00 & $157.19 \pm 8.59$ & 133.00 & 168.00 \\
Body Mass (kg) & $54.80 \pm 9.81$ & 52.10 & 57.51 & $49.07 \pm 8.49$ & 28.30 & 63.00 \\
Sitting Height (cm) & $81.07 \pm 8.17$ & 57.00 & 96.00 & $78.19 \pm 8.18$ & 58.00 & 89.50 \\
Leg Length (cm) & $84.23 \pm 10.81$ & 38.50 & 113.00 & $79.00 \pm 6.07$ & 67.00 & 89.00 \\
Arm Span (cm) & $169.76 \pm 12.66$ & 143.00 & 196.00 & $160.39 \pm 10.10$ & 139.00 & 178.00 \\
Arm Muscle Area (cm $\left.{ }^{2}\right)$ & $23.51 \pm 2.59$ & 17.87 & 29.96 & $21.14 \pm 1.89$ & 18.23 & 25.46 \\
Offset maturity (years) & $-0.54 \pm 1.68$ & -3.81 & 3.14 & $0.68 \pm 1.39$ & -2.98 & 3.16 \\
PFA (kgf) & $25.97 \pm 10.75$ & 9.96 & 55.05 & $21.41 \pm 8.69$ & 7.45 & 36.23 \\
\hline
\end{tabular}

Note. PFA: propulsive force of the arm; SD: Standard deviation

The values of the linear relationships with the variable propulsive force of the arm for boys were: arm muscle area $\left(\mathrm{R}^{2}=0.12 ; \mathrm{p}<0.01\right)$, arm span $\left(\mathrm{R}^{2}=0.21, \mathrm{p}<0.01\right)$, and maturity offset $\left(\mathrm{R}^{2}=0.20, \mathrm{p}<0.01\right)$, whilst in girls these values were: arm muscle area $\left(R^{2}=0.07 ; p=0.20\right)$, arm $\operatorname{span}\left(R^{2}=0.50\right.$, $\mathrm{p}<0.01)$, and maturity offset $\left(\mathrm{R}^{2}=0.44 \mathrm{p}<0.01\right)$, respectively (figure 1$)$. Body height, body mass, sitting height $(\mathrm{cm})$, and leg length did not contribute significantly to the parsimonious relationship with the propulsive force of the arm, suggesting that the advantage of having a longer arm span, arm muscle area, and maturity offset seem to be "limb specific" rather than a more general whole-body advantage.

Thus, three different models were developed (table 2 and table 3). However, model 3 fitted the data better than model 2 [deviance model $3=4341.45$ and deviance model $2=4475.89 ; \Delta d=-134.44]$ and model 1 

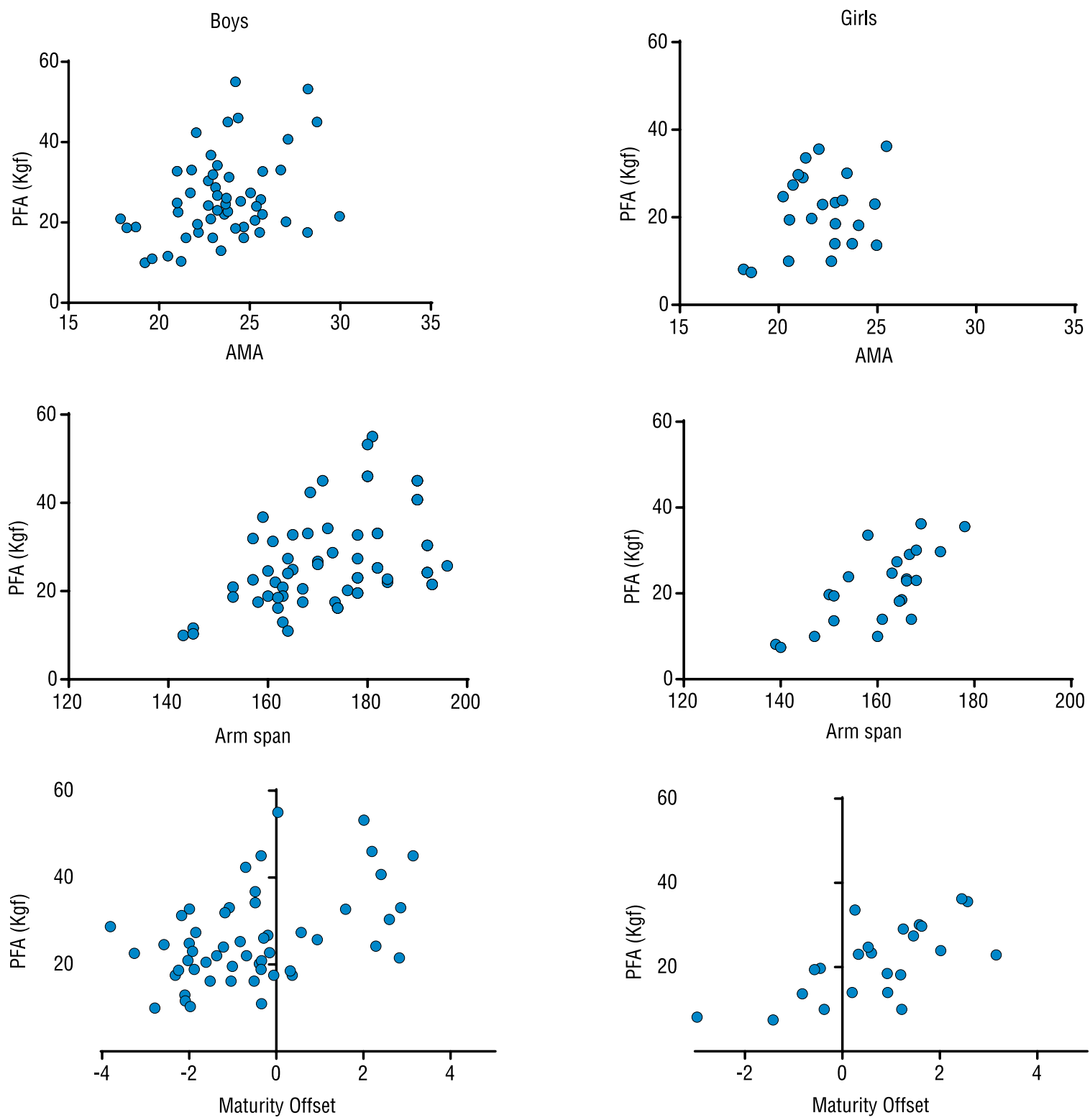

Figure 1. Correlations between PFA (propulsive force of the arm) and independent variables in boys and girls: AMA (Arm muscle area), Arm Span and Maturity Offset.

Table 2. Linear regression of the Propulsive Force of the arm by Arm muscle area, peak height velocity, and age in front crawl swimming youth athletes in boys

\begin{tabular}{|c|c|c|c|c|c|c|c|c|c|c|c|c|}
\hline \multicolumn{13}{|c|}{$\begin{array}{l}\text { Propulsive Force of the arm (kgf) } \\
\text { Boys }(n=53)\end{array}$} \\
\hline & \multicolumn{3}{|c|}{ Crude $(n=53)$} & \multicolumn{3}{|c|}{ Model $1(n=53)$} & \multicolumn{3}{|c|}{ Model $2(n=53)$} & \multicolumn{3}{|c|}{ Model $3(n=53)$} \\
\hline & $\beta$ & $95 \% \mathrm{Cl}$ & $p$ & $\beta$ & $95 \% \mathrm{Cl}$ & $p$ & $\beta$ & $95 \% \mathrm{Cl}$ & $p$ & $\beta$ & $95 \% \mathrm{Cl}$ & $p$ \\
\hline AMA $\left(\mathrm{cm}^{2}\right)$ & 1.45 & 0.39 to 2.51 & $<0.01$ & 1.45 & 0.39 to 2.51 & $<0.01$ & 0.42 & -0.90 to 1.75 & 0.52 & 0.16 & -1.22 to 1.55 & 0.81 \\
\hline Arm span & 0.38 & 0.17 to 0.59 & $<0.01$ & - & - & - & 0.32 & 0.05 to 0.59 & 0.02 & 0.21 & -0.11 to 0.54 & 0.19 \\
\hline $\begin{array}{l}\text { Maturity } \\
\text { OffSet }\end{array}$ & 2.85 & 1.29 to 4.42 & $<0.01$ & - & - & - & - & - & - & 1.49 & -0.94 to 3.94 & 0.22 \\
\hline (Constant) & & - & & -8.18 & -33.32 to 16.95 & 0.51 & -39.68 & -75.13 to -4.22 & 0.02 & -13.48 & -68.91 to 41.95 & 0.62 \\
\hline
\end{tabular}

Note. Maturity offset (Years); AMA (Arm Muscle area) $\mathrm{cm}^{2}$; Arm span (cm); Model 1 ( $R^{2}=0.12 ; \operatorname{Radj} 2=0.11 ; p=<0.01$; Deviance $=5002.85$ ); Model $2\left(R^{2}=0.22 ; \operatorname{Radj} 2=0.18 ; p=<0.01 ;\right.$ Deviance $\left.=4475.89\right)$; Model $3\left(R^{2}=0.24 ;\right.$ Radj2=0.19; $p=<0.01 ;$ Deviance $=4341.45 ;$ Std. error of the estimate $=0.70$ ) 
[deviance model $3=4341.45$ and deviance model $1=5002.85 ; \Delta \mathrm{d}=-661.4$ ] for boys. Whilst in girls the deviance value differences for model 2 were [deviance model $3=763.80$ and deviance model $2=810.77 ; \Delta \mathrm{d}=-46.97$ ] and model 1 [deviance model $3=763.80$ and deviance model 1=1540.39; $\Delta \mathrm{d}=-776.59]$.

The Bland-Altman analysis demonstrated agreement between the values obtained by both propulsive force of the arm (PFA) and propulsive force - estimated (PFE) methods (95\% confidence interval [CI]: -17.87 to $17.95 \mathrm{kgf})$ for boys and (95\% confidence interval [CI]: -11.54 to 11.55 $\mathrm{kgf}$ ) for girls (figure 2).

Finally, the correlation was verified between variables and a value of adjusted R-squared $\left(\mathrm{R}_{\text {adj }}{ }^{2}\right)$ for boys $\left(\mathrm{R}^{2}=0.24 ; \mathrm{R}_{\text {adj }}{ }^{2}=0.19 ; \mathrm{p}=<0.01\right.$; Deviance $=4341.45$; Std. error of the estimate $=0.70)$ and girls $\left(R^{2}=0.54\right.$; $\left.\mathrm{R}_{\text {adj }}{ }^{2}=0.46 ; \mathrm{p}=<0.01\right)$; Deviance $=763.80$; Std. error of the estimate $=1.33$ ) confirming that PFA and PFE are correlated and equivalent, which suggests the following equation:

PFE (boys) $=-13.480+\left[0.165 \cdot\right.$ Arm Muscle Area $\left.\left(\mathrm{cm}^{2}\right)\right]+[0.214 \cdot$ arm span $]+[1.449 \cdot$ maturity offset (years)]

PFE (girls) $=-39.200+\left[-0.681 \cdot\right.$ Arm Muscle Area $\left.\left(\mathrm{cm}^{2}\right)\right]+[0.464 \cdot \operatorname{arm}$ span $]+[1.857$. maturity offset (years)]

Table 3. Linear regression of the Propulsive Force of the arm by Arm muscle area, peak height velocity, and age in front crawl swimming youth athletes in girls.

\begin{tabular}{|c|c|c|c|c|c|c|c|c|c|c|c|c|}
\hline \multicolumn{13}{|c|}{$\begin{array}{l}\text { Propulsive Force of the arm (kgf) } \\
\text { Girls }(n=23)\end{array}$} \\
\hline & \multicolumn{3}{|c|}{ Crude $(n=23)$} & \multicolumn{3}{|c|}{ Model $1(n=23)$} & \multicolumn{3}{|c|}{ Model $2(n=23)$} & \multicolumn{3}{|c|}{ Model $3(n=23)$} \\
\hline & $\beta$ & $95 \% \mathrm{Cl}$ & $p$ & $\beta$ & $95 \% \mathrm{Cl}$ & $p$ & $\beta$ & $95 \% \mathrm{Cl}$ & $p$ & $\beta$ & $95 \% \mathrm{Cl}$ & $p$ \\
\hline $\mathrm{AMA}\left(\mathrm{cm}^{2}\right)$ & 1.24 & -0.76 to 3.24 & 0.21 & 1.24 & -0.76 to 3.24 & 0.21 & -0.55 & -2.29 to 1.17 & 0.51 & -0.68 & -2.43 to 1.07 & 0.42 \\
\hline Arm span & 0.60 & 0.33 to 0.88 & $<0.01$ & - & - & - & 0.66 & 0.33 to 0.98 & $<0.01$ & 0.46 & -0.39 to 0.96 & 0.06 \\
\hline $\begin{array}{l}\text { Maturity } \\
\text { Offset }\end{array}$ & 4.17 & 2.06 to 6.28 & $<0.01$ & - & - & - & - & - & - & 1.85 & -1.73 to 5.45 & 0.29 \\
\hline (Constant) & - & & & -6.04 & -50.61 to 38.52 & 0.78 & -72.41 & -118.9 to -25.84 & $<0.01$ & -39.20 & -118.5 to 40.19 & 0.31 \\
\hline
\end{tabular}

Note. Maturity offset (Years); AMA (Arm muscle area) $\mathrm{cm}^{2} ;$ Arm Span (cm); Model 1 ( $\mathrm{R}^{2}=0.07$; Radj2=0.02; $p=0.21$; Deviance $=1540.39$ ); Model $2\left(R^{2}=0.51 ; \operatorname{Radj2}=0.46 ; p=<0.01\right.$; Deviance $\left.=810.77\right)$; Model $3\left(R^{2}=0.54 ; \operatorname{Radj2}=0.46 ; p=<0.01\right)$; Deviance $=763.80 ;$ Std. error of the estimate $=1.33$ )

Boys

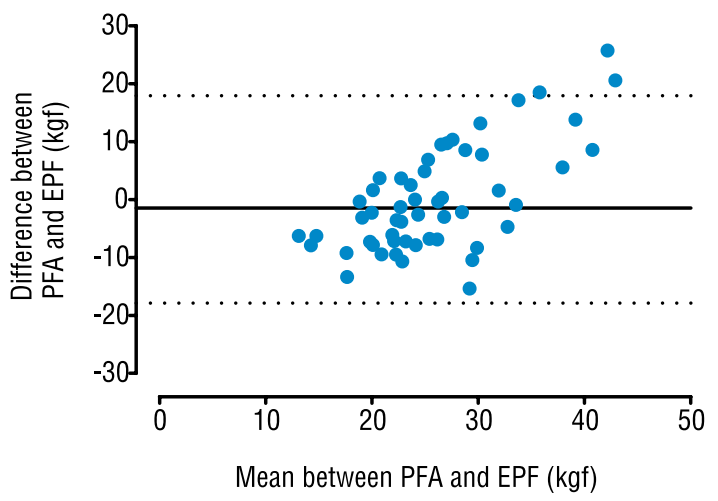

Girls

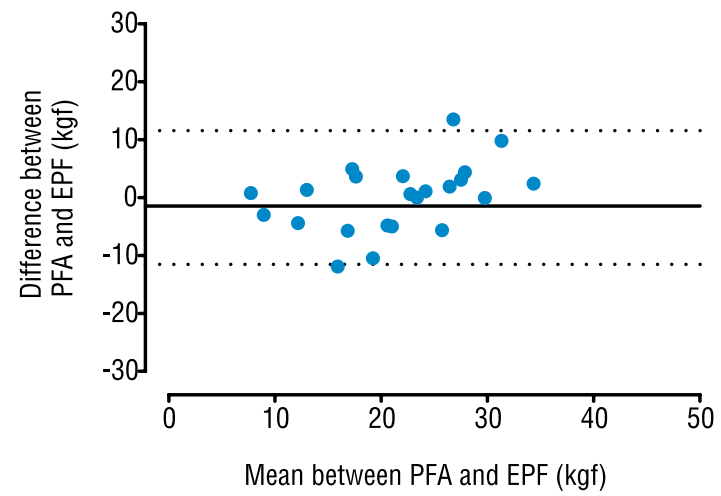

Figure 2. Bland-Altman plot between the propulsive force of the arm (PFA) and Propulsive force estimated (EPF). 


\section{DISCUSSION}

The purpose of this study was to estimate the propulsive force of the arm in young freestyle swimming and propose an equation to estimate propulsive force, considering anthropometric variables and maturity offset. Firstly, we observed that boys were older, taller, and heavier, as well as having higher propulsive force of the arm, sitting height, arm span, and arm muscle area. On the other hand, maturity offset in girls was earlier than boys. Although the maturation processes during pre-puberty and puberty are apparently independent, maturity markers are positively correlated, suggesting that an individual with advanced/delayed sexual maturation will have an advanced/delayed increase in body height ${ }^{18}$. Thus, it appears that the different stages of biological maturation (i.e., the age at which various percentages of individuals reach adult body height, the age at which different stages of skeletal maturation are achieved, and the age of peak height velocity), can occur together and alongside one another ${ }^{19}$.

The main results observed in the present study were positive associations between the propulsive force of the arm, maturity offset, arm span, and AMA, allowing, through linear regression analysis, the elaboration of a prediction equation of PFA. The values obtained demonstrate a good level of agreement between the values measured and those estimated by the equation. It was interesting to note that in model 3, for both boys and girls, the joint variables (i.e., arm span, AMA, and maturity offset), showed a lower value of deviance. One of the main challenges related to athlete performance is to identify which variables can predict athletic success. Some anthropometric factors, such as arm span, and biomechanical, technical, and kinetic variables related to the propulsive force of the arm appear as possible performance indicators in swimming athletes ${ }^{1,2,4,20,21}$.

The power generated by upper limbs has been strongly correlated with swimming velocity in young swimmers, since the fastest athletes have a greater ability to produce propulsive force, to the extent that the efficient technical gesture becomes less important in the final performance of the race through the water ${ }^{22}$. In this scenario, previous literature supports a positive relationship between power and speed and implied that high levels of power are transferred positively to the traveling speed ${ }^{13,14}$. In this sense, although the factors that influence the drag propulsion of the swimmer are known, the capacity to generate propulsive force from a larger area of muscle is not yet completely clear. In this way, a propulsive force prediction equation could help control training prescription, follow-up of training routines, and/or even the identification of new sports talents ${ }^{23}$.

However, it has already been demonstrated that there are no statistically significant differences between the relative contribution of the propulsive phase in conventional swimming in swimmers; therefore, there are slight variations between individuals in the in-water phase. In addition, it is important to consider the relative homogeneity of factors related to the environment (zero body drag due to null velocity), task (tethered swim- 
ming at a maximum intensity and without breathing), and individual (sex, competitive level, and anthropometry), found in this study. Under these conditions, both the absolute and relative duration of the stroke phases tend to have more moderate interindividual variations ${ }^{24}$.

The $M_{\text {off }}$ presented a very relevant association with the PFA, indicating that with the advancement in biological maturation, there is improvement in the power capacity of young swimmers. Growth indicators in young swimmers are minor before the onset of puberty, but during biological maturation anthropometric changes strongly affect swimming performance. Our results, corroborates the idea of evaluating peak height velocity $(\mathrm{PHV})$ as a biological maturation indicator ${ }^{25}$ and a predictor related to generating propulsive force of the arm in young swimmers. In addition, Caputo et al. ${ }^{26}$ reported that for short duration events in which the power production capacity is considered a key variable, physical characteristics such as body height, arm span, body composition, and somatotype can also contribute to the level of performance. These morphological attributes largely depend on genetic factors and may have a decisive influence on swimming performance ${ }^{27}$.

The AMA is also related to PFA and, consequently, with individual strength capacity. Muscle size is a major factor contributing to improved capacity to produce force as children pass through biological maturation. In this context, Morais et al. ${ }^{28}$, showed that improvement in force production affected stroke parameters, which ultimately affected swimming performance. This result could help the elaboration of training programs, since the inclusion of strength training in the upper body seems to be crucial to increase propulsion in the water ${ }^{4}$ and leads to an increase in AMA (i.e., elbow flexion and extension) and, consequently, can improve swimmer performance ${ }^{5,8,29}$. Programs that improve the overall strength and power in youth swimmers have a positive effect on enhancing their performance $^{28}$. It is important to highlight that fat mass and lean mass both seem to contribute to the performance of swimmers ${ }^{21}$. Swimming does not appear to favor large gains in muscle mass as these gains would reduce floatability and impair performance ${ }^{6,29}$.

This study presented limitations, as the correlations presented here were obtained according to swimmers' upper limb strength; however, the semi-tethered encoder recordings might not just be from the arm action throughout the underwater stroke, but also from the leg action. However, the equation proposed in the present study included, as predictors, the AMA, arm span, and maturity offset, presenting higher values of agreement between the propulsive force of the arm (PFA) and propulsive force-estimated (PFE). Thus, it is possible to affirm that biological maturation, arm span, and an increase in AMA are important variables that can influence propulsive force production capacity and, consequently, sports performance ${ }^{5}$.

In a way, the proposed equation may facilitate PFA measurement and help in selecting the best type of training for athletes, since the AMA, 
PHV, and age help to increase force production capacity, which can lead to a better yield. The ease with which these variables can be collected, compared to the difficulty in accessing equipment such as dynamometers, helps to justify the relevance of the study findings. Furthermore, the fact our sample was composed of federated athletes of both sexes and the PFA was assessed in an aquatic environment, makes the results found more reliable than analyzes performed in a condition that is farther from the reality of the evaluated swim. This makes the equation a valid alternative to assist the coaching of young swimmers.

\section{CONCLUSION}

The parameters AMA, arm spam, and maturity offset were more closely associated with an increase in propulsive force of the arm and, hypothetically, with performance in conventional swimming. In addition, these variables can be used in the prediction equation to estimate the propulsive force of the arm in both sexes.

\section{COMPLIANCE WITH ETHICAL STANDARDS}

\section{Funding}

This research did not receive any specific grant from funding agencies in the public, commercial, or not-for-profit sectors.

\section{Ethical approval}

Ethical approval was obtained from the Institutional Ethics Board [University of Pernambuco, Recife-PE (CAAE-23474613.6.0000.5207)], and the protocol was written in accordance with the standards established by the Declaration of Helsinki.

\section{Conflict of interest statement}

The authors have no conflict of interests to declare.

\section{Authors Contributions}

Conception and design of the experiment: MNSO; DRQ; MAMS. Realization of the experiments: MNSO; DRQ; MSFC; AHOS; JFS; WCMV; MAMS. Data analysis: MNSO; DRQ. Contribution with reagents/ research materials/analysis tools: MNSO; DRQ; MAVCJ; JCFJ. Article Writing: MNSO; DRQ; MSFC; AHOS; JFS; MAVCJ; WCMV; JCFJ; MAMS. All authors read and approved the final version of the manuscript.

\section{REFERENCES}

1. Barbosa TM, Morais JE, Marques MC, Costa MJ, Marinho DA. The Power Output and Sprinting Performance of Young Swimmers. J Strength Cond Res 2015;29(2):440-50.

2. Crowley E, Harrison AJ, Lyons M. The Impact of Resistance Training on Swimming Performance: A Systematic Review. Sport Med 2017;47(11):2285-307. 
3. Toussaint HM, Roos PE, Kolmogorov S. The determination of drag in front crawl swimming. J Biomech 2004;37(11):1655-63.

4. Muniz-Pardos B, Gomez-Bruton A, Matute-llorente A, Gonzalez-Aguero A, Gomez-Cabello A, Gonzalo-Skok O, et al. Nonspecific Resistance Training and Swimming Performance : Strength or Power? A Systematic Review. J Strength Cond Res in press

5. Cochrane KC, Housh TJ, Smith CM, Hill EC, Jenkins NDM, Johnson GO, et al. Relative Contributions of Strength, Anthropometric, and Body Composition Characteristics to Estimated Propulsive Force in Young Male Swimmers. J Strength Cond Res 2015;29(6):1473-9.

6. Nevill AM, Negra Y, Myers TD, Sammoud S, Nevill AM. Key somatic variables associated with, and differences between the 4 swimming strokes strokes. J Sports Sci 2020;38(7):787-94.

7. Nevill AM, Oxford SW, Duncan MJ. Optimal Body Size and Limb Length Ratios Associated with 100-m Personal-Best Swim Speeds. Med Sci Sport Exerc 2015;47(8):1714-8.

8. Santos MAM, Barbosa Junior ML, Melo WVDC, Costa AV, Costa MDC. Estimate of propulsive force in front crawl swimming in young athletes. Open Access J Sport Med 2012;3(1):115-20.

9. Morouço PG, Marinho DA, Izquierdo M, Neiva H, Marques MC. Relative Contribution of Arms and Legs in 30 s Fully Tethered Front Crawl Swimming. Biomed Res Int 2015;2015: 563206.

10. Morais JE, Saavedra JM, Costa MJ, Silva AJ, Marinho DA, Barbosa TM. Tracking young talented swimmers: Follow-up of performance and its biomechanical determinant factors. Acta Bioeng Biomech 2013;15(3):129-38.

11. Sammound S, Nevill AM, Negra Y, Bouguezzi R, Chaabene H, Hachana Y. Allometric Associations between Body Size, Shape, and 100-m Butterfly Speed Performance. J Sports Med Phys Fitness 2018; 58(5):630-637.

12. Papoti M, Martins L, Cunha S, Zagatto A, Gobatto C. Padronização de um protocolo específico para determinação da aptidão anaeróbia de nadadores utilizando células de carga. Rev Port Ciên Desporto 2003;2003(3):36-42.

13. Judge LW, Moreau C, Burke JR. Neural adaptations with sport-specific resistance training in highly skilled athletes. J Sports Sci 2003;21(5):419-27.

14. Swaine IL. Arm and leg power output in swimmers during simulated swimming. Med Sci Sports Exerc 2000;32(7):1288-92.

15. Geladas ND, Nassis GP, Pavlicevic S. Somatic and physical traits affecting sprint swimming performance in young swimmers. Int J Sports Med 2005;26(2):139-44.

16. Morais JE, Costa MJ, Mejias EJ, Marinho DA, Silva AJ, Barbosa TM. Morphometric study for estimation and validation of trunk transverse surface area to assess human drag force on water. J Hum Kinet 2011;28(1):5-13.

17. Mirwald RL, Baxter-Jones ADG, Bailey DA, Beunen GP. An assessment of maturity from anthropometric measurements. Med Sci Sports Exerc 2002;34(4):689-94.

18. Beunen GP, Rogol AD, Malina RM. Indicators of Biological Maturation and Secular Changes in Biological Maturation. Food Nutr Bull 2006;27(supp1 5):S244-56.

19. Malina R. Secular trends in growth, maturation and physical performance: a review. Anthr Rev 2004;67:3-31.

20. Morais JE, Marques MC, Marinho DA, Silva AJ, Barbosa TM. Longitudinal modeling in sports: Young swimmers' performance and biomechanics profile. Hum Mov Sci 2014;37:111-22.

21. Saavedra JM, Escalante Y, Rodríguez FA. A multivariate analysis of performance in young swimmers. Pediatr Exerc Sci 2010;22(1):135-51.

22. Barbosa TM, Costa MJ, Morais JE, Morouço P, Moreira M, Garrido ND, et al. Characterization of speed fluctuation and drag force in young swimmers: A gender comparison. Hum Mov Sci 2013;32(6):1214-25. 
23. Akşit T, Zeki Özkol M, Vural F, Pekünlü E, Aydinoğlu R, Varol R. Contribution of anthropometric characteristics to critical swimming velocity and estimated propulsive force. J Phys Educ Sport 2017;17(1):212-8.

24. Seifert L, Chollet D, Rouard A. Swimming constraints and arm coordination. Hum Mov Sci 2007;26(1):68-86.

25. Machado DRL, Bonfim MR, Costa LT. Pico de velocidade de crescimento como alternativa para classificação maturacional associada ao desempenho motor. Rev Bras Cineantropom Desempenho Hum 2009;11(1):14-21.

26. Caputo F, Oliveira MFM, Denadai BS, Greco CC. Fatores intrínsecos do custo energético da locomoção durante a natação. Rev Bras Med do Esporte 2006;12(6):399-404.

27. Lätt E, Jürimäe J, Haljaste K, Cicchella A, Purge P, Jürimäe T. Longitudinal Development of Physical and Performance Parameters during Biological Maturation of Young Male Swimmers. Percept Mot Skills 2009;108(1):297-307.

28. Morais JE, Silva AJ, Garrido ND, Marinho DA, Barbosa TM. The transfer of strength and power into the stroke biomechanics of young swimmers over a 34week period. Eur J Sport Sci 2018;18(6):787-95.

29. Oliveira M, Henrique RS, Queiroz DR, Salvina M, Melo WV, Santos MA. Anthropometric variables, propulsive force and biological maturation: A mediation analysis in young swimmers. Eur J Sport Sci in press.

Corresponding author

Daniel da Rocha Queiroz

R Arnóbio Marques 310, CEP 50100-130 - Recife, PE, Brasil.

E-mail: efdanielrocha@live.com 